\title{
New species of Harperia, Loxocarya, Onychosepalum, Platychorda and Tremulina (Restionaceae) in Western Australia
}

\author{
Barbara G. Briggs and L.A.S. Johnson ${ }^{\dagger}$
}

\begin{abstract}
Briggs, Barbara G. and Johnson, L.A.S. (Royal Botanic Gardens, Mrs Macquaries Road, Sydney, NSW 2000, Australia) 2001. New species of Harperia, Loxocarya, Onychosepalum, Platychorda and Tremulina (Restionaceae) in Western Australia. Telopea 9(2): 247-257. Five new species of Restionaceae in the southern half of Western Australia are described; all having rare, vulnerable or endangered conservation status. Harperia eyreana, from the coastal southeast of that State, is the fourth species of its genus. Loxocarya gigas, from north of Perth is the largest of Australia's Restionaceae and the fifth species now referred to that genus, which until recently was confused with Desmocladus. Onychosepalum nodatum, also from north of Perth, brings to three the members of its genus. Platychorda rivalis and Tremulina cracens are plants of moist habitats in the south-west; the only other members of these genera, P. applanata and T. tremula, were recently excluded from Restio.
\end{abstract}

\section{Introduction}

The species described below all occur in the southern half of Western Australia. All were listed in our classification of Restionaceae (Briggs \& Johnson 1999), in advance of formal description, and further information on most of them is given by Meney, Pate and Hickman (1999), who also provide excellent illustrations. An account of all species of the genera concerned will be given in the Flora of Australia (Briggs, Johnson, Porter \& Krauss, in preparation).

\section{Descriptions of new species}

Harperia W. Fitzg.

Until recently Harperia was considered to be monotypic, with only the single species, $H$. lateriflora W. Fitzg. It has been enlarged by the description of the very rare species H. ferruginipes K.A. Meney \& J.S. Pate (Meney et al. 1996) and the transfer from Restio of H. confertospicatus (Steud.) B.G. Briggs \& L.A.S. Johnson. One further, recently discovered, species from the south-east of Western Australia is here described. These additional species widen the diversity of features within the genus to include caespitose as well as rhizomatous species and ones with much-branched culms, whereas the type species shows little culm branching. All share spikelets of generally similar form and distinctive culm anatomy with extensive development of sclerenchyma in the central ground tissue (Linder et al. 1998; Briggs \& Johnson 1999; Meney, Pate \& Hickman 1999) and all occur in the southern half of Western Australia. 
Harperia eyreana B.G. Briggs E L.A.S. Johnson, sp. nov.

A Harperia ferruginipes combinatione characterum sequentium distinguitur: habitus caespitosus; pili basales pallidi; culmi 1-1.5 mm diametro, ramosissimi flexuosique; vaginae basales glabrae; vaginae culmorum appressae.

Type: c. $20 \mathrm{~km} \mathrm{SW}$ of Cocklebiddy, Twilight Cove road, 32 ${ }^{\circ} 11^{\prime} \mathrm{S} 126^{\circ} 03^{\prime} \mathrm{E}, 3$ Dec 1993, S. Jacobs 7045 q (holo NSW; iso K, MEL, MO, PERTH).

Caespitose, forming large, dense or rather open, many-stemmed tussocks, $25-120 \mathrm{~cm}$ across. Rhizome pubescent with white or pale tan hairs; basal scales glabrous, scarious or hyaline, ovate, $0.5 \mathrm{~cm}$ long, \pm glossy. Culms erect or \pm spreading, terete, $35-120 \mathrm{~cm}$ tall, 1-1.5 mm diam., finely tuberculate, bright green, glabrous; internodes numerous, $1.5-4.5 \mathrm{~cm}$ long; repeatedly branched, the branches slender, highly flexuose. Culm sheaths: appressed, oblong, 7.5-12 mm long, red-brown, apex obtuse or truncate, often with soft, white axillary hairs projecting beyond the sheath, lamina 1.0-2.5 mm long. Spikelets usually solitary on branches; glumes glabrous, tan-brown. Male spikelets narrow-cylindrical, 5-8.5 mm long; glumes 1.4-3.0 mm long, 3-5 lower glumes rigid, broad-ovate, apex obtuse to obcordate, with a black mucro to $1.5 \mathrm{~mm}$ long; upper glumes 15-22, blunt, hyaline, ovate to oblong, not mucronate, only c. 5 uppermost subtending flowers. Female spikelets narrow ovoid-cylindrical, $6.5-8.5 \mathrm{~mm}$ long, 1-flowered; glumes 5-7, narrow-ovate, acute, $1.8-5.0 \mathrm{~mm}$ long; mucro rigid, black, 1.1-2.5 mm long. Male flowers: tepals 5, hyaline, filiform, 1.6-2.5 mm long; filaments c. $3 \mathrm{~mm}$ long; anthers $1 \mathrm{~mm}$ long. Female flowers: tepals (4-)5, hyaline, narrow elliptic, obtuse, shed with the nut, 4.0-5.5 mm long. Nut narrow oblong, 3.5-4.5 mm long, pale brown, with a short thick stipe above the tepals. Seed oblong, c. $2.5 \mathrm{~mm}$ long. (Fig. 1a-1d.)

The epithet commemorates Edward John Eyre who, despite great difficulties, in 1841 first explored the region in which it occurs. This region was designated the Eyre botanical district by Diels (1906), but has subsequently been subdivided into several phytogeographic areas.

Distribution: occurs in Western Australia south of Cocklebiddy. On deep white sand or calcareous loamy sand in tall shrubland of mallee eucalypts and Callitris. On crest and leeward side of white calcareous stabilised dune and on sand over limestone pavement.

Conservation status: listed as Rare, Western Australian Department of Conservation and Land Management (CALM) code Priority 2 (P2) (Meney, Pate, Dixon, Briggs, \& Johnson 1999). Known from very few localities in a very restricted area, but occurring in a nature reserve and in a remote region where the vegetation may not be subject to gross disturbance or clearing.

The culms and spikelets of $H$. eyreana resemble those of $H$. ferruginipes but the former is distinguished by the caespitose habit; basal scales glabrous; basal hairs pale; culms more slender, more intricately branched and flexuose; culm sheaths appressed. $H$. ferruginipes has dark, ginger-brown hairs on its stout rhizomes and on basal scales, culms 1.5-2 mm diam., and culm sheaths that become lax with age (Fig. $1 \mathrm{e}$ ).

Specimens examined: Western Australia: Eucla: $20 \mathrm{~km} \mathrm{SSW}$ of Cocklebiddy along track to Twilight Cove, 4 Jan 1979, Crisp 4774 ? (CANB, NSW); $20 \mathrm{~km} \mathrm{SW}$ of Cocklebiddy (details as for type) 7040 ơ (NSW), 7043 ơ (NSW, PERTH), 7051 ô (NSW, CANB, PERTH), 7046, 7050 ๆ (NSW); $25 \mathrm{~km} \mathrm{SE}$ of Cocklebiddy, 13 Dec 1986, Newby 11428 \& (PERTH, NSW); $36 \mathrm{~km}$ SE of Cocklebiddy on road to Eyre Bird Observatory, c. 19 km S of Hwy, 4 Dec 1993, Jacobs 7052 ô, 7053 q (NSW, AD, PERTH); $19.7 \mathrm{~km}$ from Eyre Hwy on road to Eyre Bird Observatory, Nuytsland Nature Reserve, 26 Oct 1995, Johnstone 619 \& Sweedman + (NSW, AD, CANB, K, MEL, MO, NBG, NY, PERTH, RSA). 


\section{Loxocarya R. Br.}

The past confusion between Loxocarya and Desmocladus, which have superficial similarities in some of their species but are not closely related, is outlined by Briggs \& Johnson (this issue, and references therein). Loxocarya includes two species distinguished early in studies of Australian Restionaceae, L. cinerea R. Br. and L. striata (F. Muell.) B.G. Briggs \& L.A.S. Johnson, and two that have been recently named, L. magna K.A. Meney \& K.W. Dixon and L. albipes J.S. Pate \& K.A. Meney. One further species has been distinguished and is described here.

Loxocarya gigas B.G. Briggs \& L.A.S. Johnson, sp. nov.

Inter species Loxocarya statura majore distinguitur; rhizomata 7-10 mm diametro; culmi ad 2(-2.5) m longi; spiculae femineae $3-5 \mathrm{~cm}$ longae; ramuli inflorescentiarum feminearum 25-45 cm longis; fructus c. $10 \mathrm{~mm}$ longi.
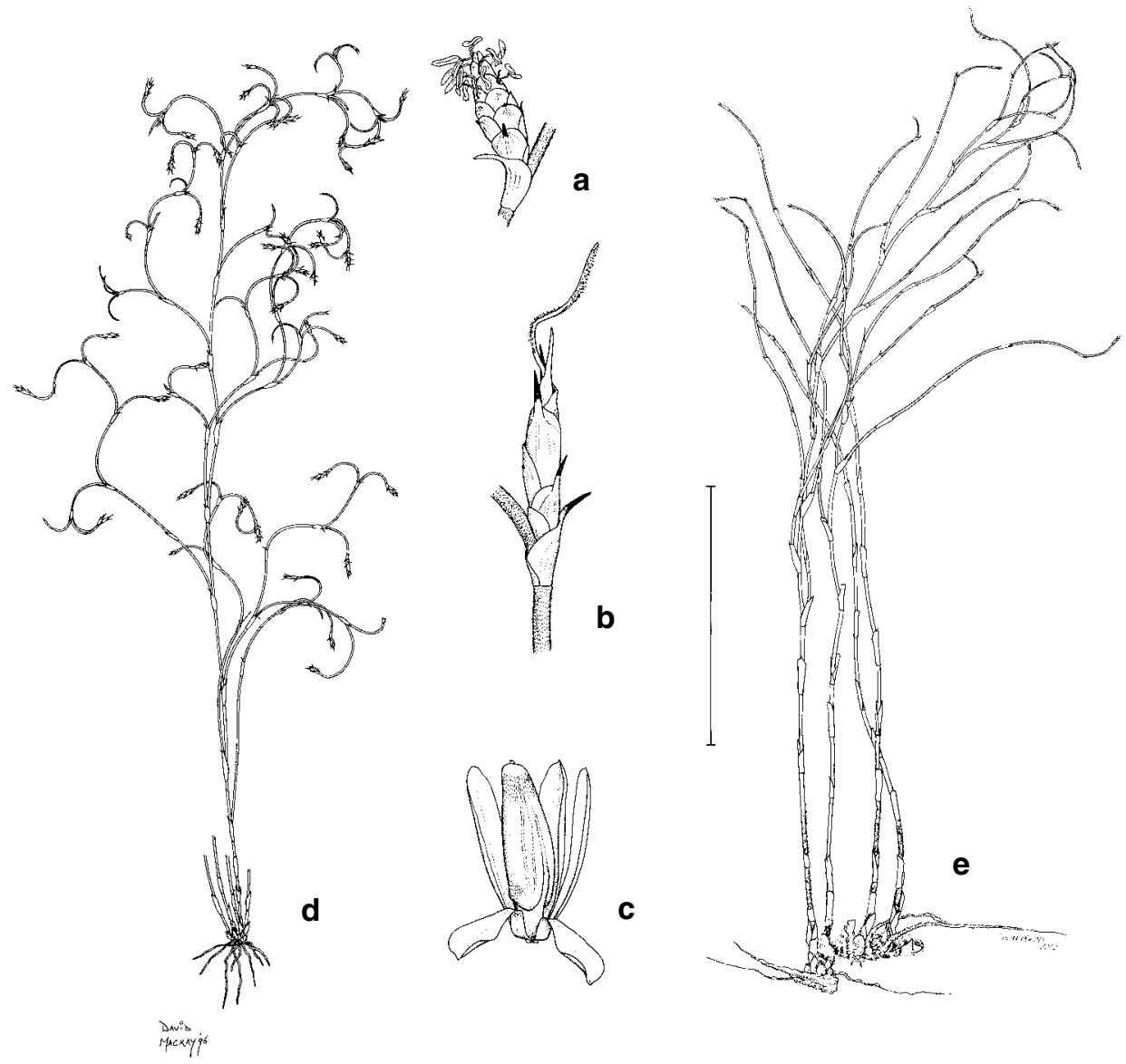

Fig. 1. a-d, Harperia eyreana, a, male spikelet (Jacobs 7043); b-d, female: b, spikelet; $\mathbf{c}$, nut with bract and tepals; d, habit (Jacobs 7045). e, Harperia ferruginipes, habit female (5 km S of Geraldton-Mullewa Rd, Pate NSW 363212). Scale bar: $a \& b=9.5 \mathrm{~mm} ; \mathrm{c}=6.7 \mathrm{~mm} ; \mathrm{d} \& \mathrm{e}=10 \mathrm{~cm}$. 
Type: Western Australia: 22.8 km E of Brand Hwy on Green Head-Coorow Road, Alexander Morrison Natl Park, 3001'S 115²0'E, 30 Sep 1984, B.G. Briggs 7727 \& L.A.S. Johnson 9 (holo NSW; iso AD, BRI, CANB, DNA, K, MEL, MO, NBG, PERTH, RSA).

Forming large tussocks of numerous culms linked by interlacing rhizomes. Rhizomes stout, to $20 \mathrm{~cm}$ long, 7-10 mm diam.; sheaths straw-coloured, partly covering a dense white pubescence. Culms spaced c. $2 \mathrm{~cm}$ apart, stout, erect, terete to sub-terete, finely striate, $1.5-2(-2.5) \mathrm{m}$ long, 7-8 $\mathrm{mm}$ diam. at the base, $4.5-5.0 \mathrm{~mm}$ diam. mid-culm, internodes 9-12 cm long, fistular, bright green or yellow-green, glabrous above, hoarytomentose basally; upper branches flattened adaxially, concavo-convex; culm branches dimorphic: floriferous branches long, straight; sterile branches short, mostly 5-20 cm long, densely branched into filiform segments with short internodes. Sheaths of culms and fertile branches $2-3 \mathrm{~cm}$ long, brown, glabrous or shortly hoary, often apically shortly ciliate, apex acute to obtuse; lamina erect, 4-15 mm long, caducous; sheaths of sterile branches green or tan, auriculate, $2-5 \mathrm{~mm}$ long with a linear lamina 5-12 mm long and a tuft of white axillary hairs. Male inflorescences to $50 \mathrm{~cm}$ long, with very numerous spikelets; several secondary inflorescence branches of different lengths and degrees of branching arising at each upper culm node. Male spikelets on pedicels to $2 \mathrm{~cm}$ long, ovoid or obconical, 7-11(-25) $\mathrm{mm}$ long, 2.5-4 mm wide, with 2-4 sterile lower glumes and c. 30-50 fertile upper glumes; glumes ovate, 3.0-3.7 mm long, light brown, pubescent, apex obtuse to acute; mucro erect, terete, $1.8-2.6 \mathrm{~mm}$ long. Female inflorescence with slender lateral branches $25-45 \mathrm{~cm}$ long, of several internodes, mostly arising singly at culm nodes. Female spikelets terminal on branches, 3-5 cm long, 1.0-1.5 cm wide, with 1-3 sterile lower glumes and 1-5 fertile upper glumes; glumes rigid, becoming woody, broadly ovate, c. $1.5 \mathrm{~cm} \mathrm{long,} \mathrm{brown,}$ striate, pilose on abaxial surface and apex when young, becoming glabrous, apex aristate; mucro erect, c. 1-1.5 cm long. Male flowers: tepals 6, lanceolate, brown, hyaline, 2.5-3.3 mm long; 2 lateral outer tepals keeled; filaments 2.5-2.7 mm long; anthers $2.3 \mathrm{~mm}$ long, exserted. Female flowers: tepals apically pubescent; outer tepals rigid, elliptical, 6-10 mm long with an awn c. $10 \mathrm{~mm}$ long; inner tepals hyaline, ovate, truncate, 3-6 mm long; staminodes minute; ovary 2-locular; styles 2, shortly connate at base. Capsule c. $10 \mathrm{~mm}$ long, 4-7 mm wide; 1-5 capsules per spikelet developing. Seed oblong, furrowed on one side, 4.2-5.2 mm long, 2-3 mm wide. Chromosome number; $2 \mathrm{n}=24$ (Briggs unpublished, voucher Gittins 1696). (Fig. 2d-e).

The epithet is from the Greek giga-, giant, very large, referring to the size of the plant and its component parts.

Distribution: occurs in a few sites near and north of Badgingarra, including the Alexander Morrison National Park. Grows in shrubland and tall heath, on sand or sand over laterite, on elevated sites.

Conservation status: rare but represented in a conservation reserve, code $2 \mathrm{KCa}$ (Briggs \& Leigh 1996, listed as Restio gigas). Declared endangered rare flora, CALM code R (Meney, Pate, Dixon, Briggs, \& Johnson 1999). Endangered especially since it is an obligate seeder species killed by fire, and since plants take more than ten years after germination to reproductive maturity. This vulnerability is increased by the short period of viability of the seeds.

This is the largest of Australia's Restionaceae, with culms to $2.5 \mathrm{~m}$ tall. It is surprising that it was not distinguished until recent decades and described until now, especially since one area of occurrence is in the road reserve adjoining a major (though recently constructed) highway.

Distinguished from other species of Loxocarya (Fig. 2a-2c, 2f-2h) by the large size of all its parts, including stout rhizomes and culms; male spikelets numerous in muchbranched inflorescences; female spikelets and fruits large, on long inflorescence 


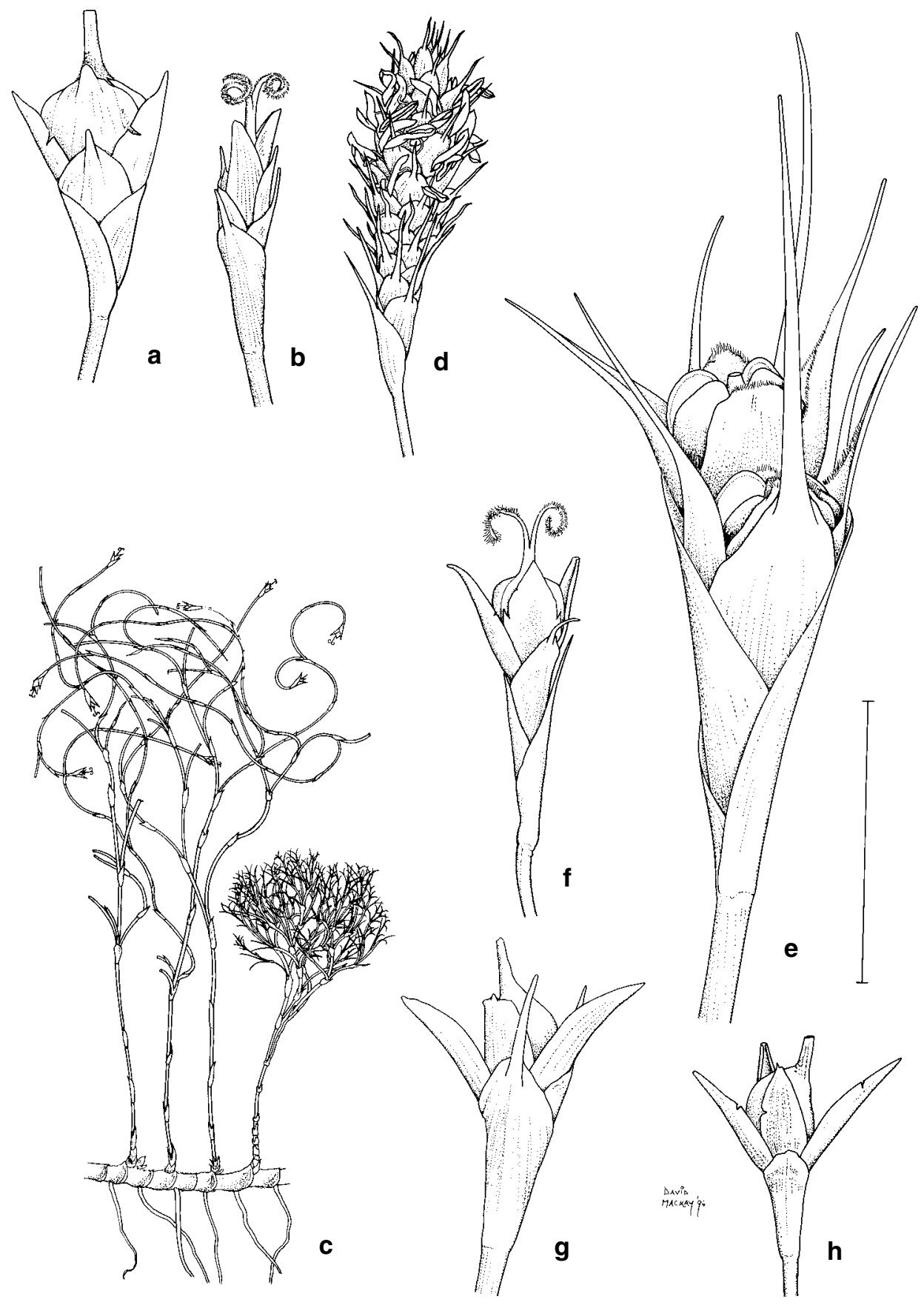

Fig. 2. Species of Loxocarya. a-c, L. striata. a, fruiting spikelet (Tutanning Reserve, Briggs 172, NSW); b, flowering female spikelet; c, habit (SE of Tambellup, Briggs 8497 E Johnson, NSW). d \& e, L. gigas, d, male spikelet (Briggs 8584 et al.); e, fruiting spikelet (Briggs 8585 et al.). f-h: fruiting spikelets: f, L. albipes (E of Wongan Hills, Pate NSW 280360); g, L. magna (ENE of Augusta, Briggs 8668, NSW); h, L. cinerea (near Karridale, Krauss 158 \& Howitt, NSW). Scale bar: a, b, d, f, g, h = 5 $\mathrm{mm} ; \mathrm{c}=8 \mathrm{~cm} ; \mathrm{e}=1.6 \mathrm{~cm}$. 
branches. Strong dimorphism of much-branched non-flowering culm branches and elongated flowering branches is a pronounced and constant feature. Culm dimorphism has not been observed in $L$ albipes (with culms all fertile, strait and unbranched below the inflorescence) and L. magna (all or most culms fertile and branched, with curled or sinuous laterals). Dimorphism in L. striata and L. cinerea ranges from not evident to pronounced (e.g. Fig. 2c).

Selected specimens examined: Western Australia: Irwin: $5 \mathrm{~km} \mathrm{NW}$ of junction of Brand Hwy and Coorow-Greenhead Rd, 19 May 1995, Corbyn 3500 of, o (PERTH, NSW); Alexander Morrison Natl Park, Dec 1972, Passfield s.n. ô, + (PERTH); c. 25 km E of Brand Hwy on Green Head to Coorow road, Alexander Morrison Natl Park, 30 Sep 1984, Briggs 7742 \& Johnson 9 (NSW, CANB, RSA); $20 \mathrm{~km}$ E of Brand Hwy on road to Coorow, 22 Apr 1989, Krauss 155 \& Howitt ô (NSW); 37 miles [60 km] W of Coorow, Sep 1967, Gittins 1696 , 1696b ơ (NSW); Reserve 27 miles [43 km] SW of Coorow, Feb 1967, Chapman s.n. $\delta^{\dagger}$, + (NSW 101134); Brand Hwy, $11.6 \mathrm{~km}$ N of Jurien turn-off (near Tootbardi Farm), c. 28 km (direct) NNW of Badgingarra, 6 Sep 1990, Briggs 8584, Johnson, Meney, Pate $\mathcal{E}$ Linder ơ (NSW, BOL, CANB), 8585 오 (NSW, BOL).

Onychosepalum Steud.

Like the related genus Harperia, Onychosepalum was considered to be monotypic until recently, including only O. laxiflorum which occurs south of the Stirling Range. The discovery of O. microcarpum K.A. Meney \& J.S. Pate (Meney, Pate \& Dixon 1996) and recognition of the species now described attest the great increase in knowledge gained in recent decades of the flora of the region between Perth and Geraldton.

Onychosepalum nodatum B.G. Briggs E L.A.S. Johnson, sp. nov.

$\mathrm{Ab} O$. laxiflorum combinatione characterum sequentium distinguitur: culmi plerumque nodo unico vaginaque parva instructi, vaginae basales pallidiores; mucrones bractearum glumarumque breviores.

Type: Western Australia; Strathmore Road Reserve (No. 26248), S of Badgingarra (30³4'S 115²1'E), 5 Nov 1975, A. George 14196 o (holo PERTH; iso NSW).

Caespitose, forming small, many-culmed tussocks. Culms erect, $8-27 \mathrm{~cm}$ long, c. $0.5 \mathrm{~mm}$ diam., yellow-green. Basal sheaths glossy, tan-brown, appressed, 0.4-2.0 cm long, with a pale mucro to $2 \mathrm{~mm}$ long; culm sheath: a single hyaline to scarious sheath present on most culms, at or usually above the culm midpoint, appressed or slightly lax, 5-12 mm long, mucro c. $3 \mathrm{~mm}$ long. Spikelets terminating culms, subtending bract $2-5 \mathrm{~mm}$ long with a mucro $0.8-1.8 \mathrm{~mm}$ long; glumes green or pale brown. Male spikelets ovoid, becoming loose and spreading, 7-8 $\mathrm{mm}$ long, 4-5 mm wide; glumes c. 40, all fertile, scarious to hyaline, ovate, $3.0-4.0 \mathrm{~mm}$ long, glabrous, truncate or auriculate, mucro 1-1.5 mm long. Female spikelets narrow ellipsoid, 7-9 mm long, c. $4 \mathrm{~mm}$ wide; glumes c. 12 , several lower ones sterile, obovate, c. $4 \mathrm{~mm}$ long; apex auriculate, shortly pilose with white hairs, mucro c. $1.5 \mathrm{~mm}$ long. Male flowers: tepals 4 , glabrous, hyaline, narrow spathulate, c. $3 \mathrm{~mm}$ long; 2 outer tepals keeled, inner tepals flat; anthers c. $1 \mathrm{~mm}$ long, exserted. Female flowers: tepals 0-3, similar to males, c. $2.5 \mathrm{~mm}$ long. Fruit not seen. (Fig. 3a-c.)

The epithet is from the Latin nodus, a node, and -atus, provided with, referring to the presence of a node and sheath on the culms.

Distribution: occurs in Western Australia at a few sites north and northwest of Cataby.

Conservation status: vulnerable, CALM code Priority 3 (Meney, Pate, Dixon, Briggs, \& Johnson 1999). Known from very few sites but poorly known, in an area subject to local mining but perhaps not yet affected by very extensive land clearance. The conservation status of this species needs further survey and monitoring. Lacking subterranean rhizomes, it would be killed by fire. 
Similar to O. laxiflorum but distinguished by one node and small sheath near the midpoint or usually in the upper half of most culms, the paler basal sheaths and glumes; bracts and glumes with shorter mucros. The mucro of the subtending bract of both male and female spikelets is $0.8-1.2 \mathrm{~mm}$ long, cf. (2-)3-5 mm in O. laxiflorum. Plants of $O$. nodatum may generally be slightly taller and have larger male spikelets than O. laxiflorum, but the collections are too few to determine the extent of variation. O. microcarpum differs in its lesser height, paler basal scales and glumes, and the females often having several spikelets per culm.

Specimens examined: Western Australia: Irwin: $10 \mathrm{~km} \mathrm{~N}$ of Cataby, Dec.1995, D. Woodman TW 17 q (PERTH), Jan 1996, D. Woodman DWT 24 क (PERTH); N Woolka Road, c. 8 km W of junction with Cooljarloo Road, 6 Nov 1988, B. Keighery 521b ô (PERTH); N Woolka Road, c. 8 km W of junction with Cooljarloo Road, 16 Oct 1990, G. Keighery 11908 ô (PERTH, NSW); Eneminga Reserve, Mar 1966, Bowler s.n. ô (PERTH, NSW 259316).
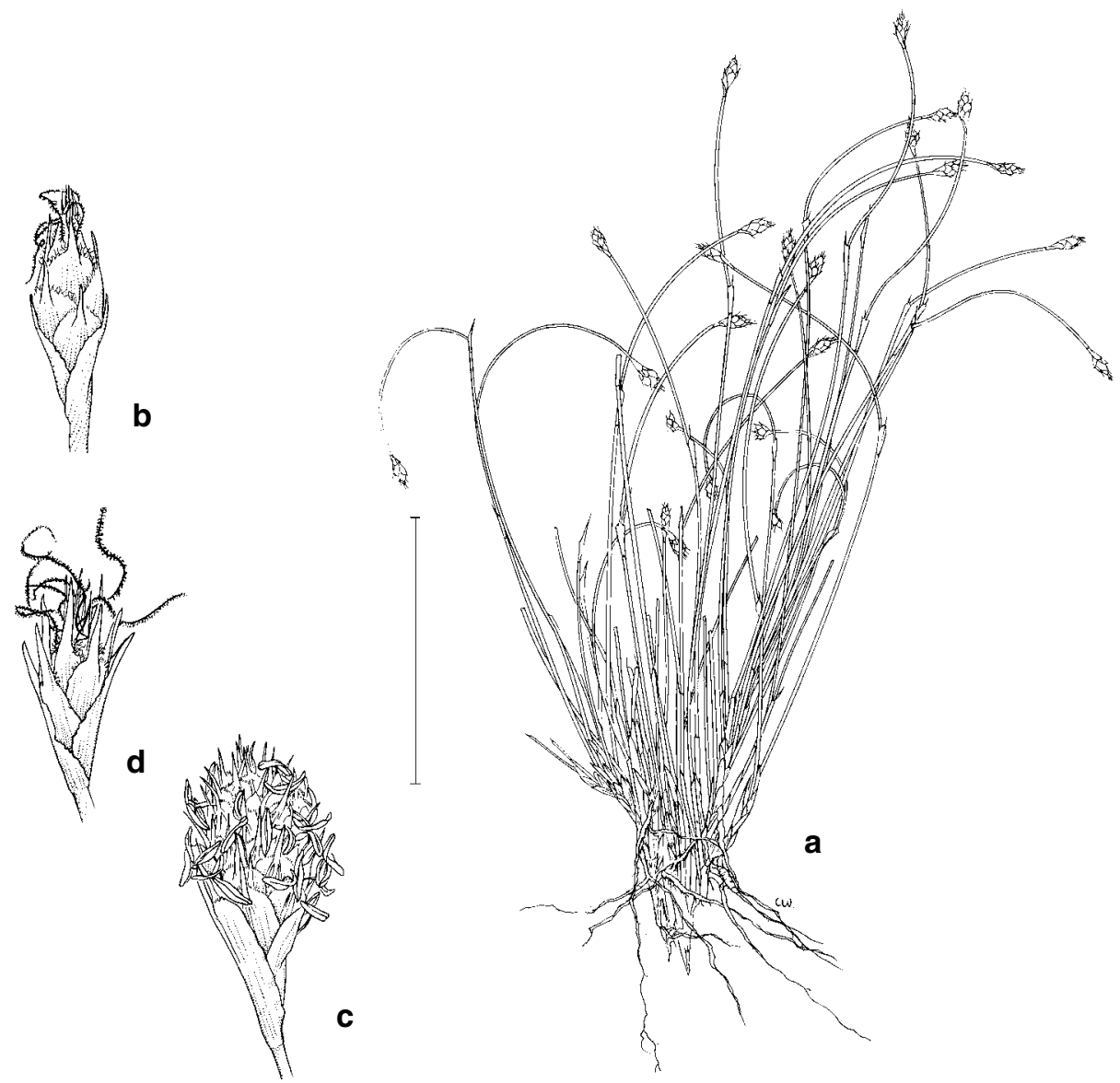

Fig. 3. a-c. Onychosepalum nodatum. a \& b, female: a, habit; b, spikelet (George 14196); c, male spikelet (Keighery 521B). d, O. laxiflorum, female spikelet (South Stirling, Briggs 6583 \& Johnson, NSW). Scale bar: $a=3 \mathrm{~cm} ; b-d=5 \mathrm{~mm}$. 


\section{Platychorda B.G. Briggs \& L.A.S. Johnson}

The recognition that Restio is a member of an African clade, which has no genera in common with the Australasian members of the family, led to the description of several genera (Briggs \& Johnson 1998) to accommodate the diverse Australian species formerly named under Restio. Among these is Platychorda, restricted to the high rainfall region of the south of Western Australia. It is distinguished from other related genera by the six tepals, trilocular ovary and three style branches in the female flowers. The type species, P. applanata (Sprengel) B.G. Briggs \& L.A.S. Johnson, occurs in seasonally inundated heaths and swamps from Augusta to Albany (Meney, Pate \& Hickman 1999). In the same region, but known from only a single locality, is the only other species of the genus, which is now described.

Platychorda rivalis B.G. Briggs E L.A.S. Johnson, sp. nov.

A Platychorda applanata combinatione characterum sequentium distinguitur: vaginae culmorum et glumae pallidiores, non nitidae; spiculae masculinae acutae; spiculae femineae longiores, acutae, flore solitario.

Type: Western Australia: Spearwood Creek, $8.3 \mathrm{~km} \mathrm{~W}$ of Sues Rd along Denny Rd, W of Nannup, 3404'12"S 115¹8'35"E, 24 Nov 1995, T.D. Macfarlane 2560 E A.R. Annels $q$ (holo PERTH; iso NSW).

Caespitose, forming dense tussocks c. $20 \mathrm{~cm}$ across; base pilose with pale hairs; basal sheaths similar to culm sheaths, glabrous. Culms erect, straight, compressed, unbranched, $60-85 \mathrm{~cm}$ long, $1.3-2.2 \mathrm{~mm}$ wide, striate, glabrous, bright green; internodes few, 8-25 cm long. Sheaths closely appressed, c. 7-15 mm long, glabrous, scarious-hyaline, brown; lamina 5-10 $\mathrm{mm}$ long, 2-2.5 $\mathrm{mm}$ broad, blunt, often weathering away. Inflorescence with short, slender, erect branches at several closelyspaced upper nodes; branches bearing several spikelets on filiform pedicels. Male spikelets narrow acute-ovoid, 4-5 mm long; glumes lanceolate, acute, dull tan-brown, glabrous or very shortly ciliate, to $4 \mathrm{~mm}$ long, lower glumes shorter. Female spikelets ovoid, 5-7 mm long, 2-3 mm wide, with 9-15 sterile lower glumes and 1 fertile upper glume; glumes similar to males; a few of the lowest glumes with a very short, blunt mucro. Male flowers: tepals 6, narrow-lanceolate, hyaline, glabrous; 2 outer tepals keeled, 3-3.5 mm long; 3rd outer tepal and inner tepals flat, slightly shorter; stamens 3; filaments c. $1 \mathrm{~mm}$ long; anthers c. 1.3-1.8 mm long, not exerted. Female flowers: tepals 6 , concave, glabrous, red-brown with broad hyaline margins, lanceolate, acute, 3-5 mm long; staminodes 3; ovary trilocular; styles 3, shortly connate at the base. Capsule c. $1.2 \mathrm{~mm}$ long. Seed ellipsoid, c. $0.9 \mathrm{~mm}$ long, pale brown. (Fig. 4a-e).

The epithet is from the Latin rivalis, pertaining to brooks or streams, referring to the habitat of the species.

Distribution: known only from Spearwood Creek, a tributary of Blackwood River, east of Margaret River. Grows on moist peaty sand in sedgeland with tall shrubs; site constantly moist with considerable seepage through the substrate.

$P$. rivalis is similar to $P$. applanata in culm anatomy, with culm chlorenchyma lacking pillar cells but interrupted by narrow, radially elongated sclerenchyma girders. The species are also similar in their seed surfaces, having an irregular pattern of subangular flat or slightly convex cells. $P$. rivalis is distinguished by the paler culm sheaths; glumes paler tan-brown, not glossy; male spikelets acute; female spikelets longer (5-7 mm long), acute, with only one flower. P. applanata has mostly tan-brown culm sheaths; glossy, dark brown glumes; male spikelets blunt; female spikelets ovoid to globular, blunt, with several flowers. 


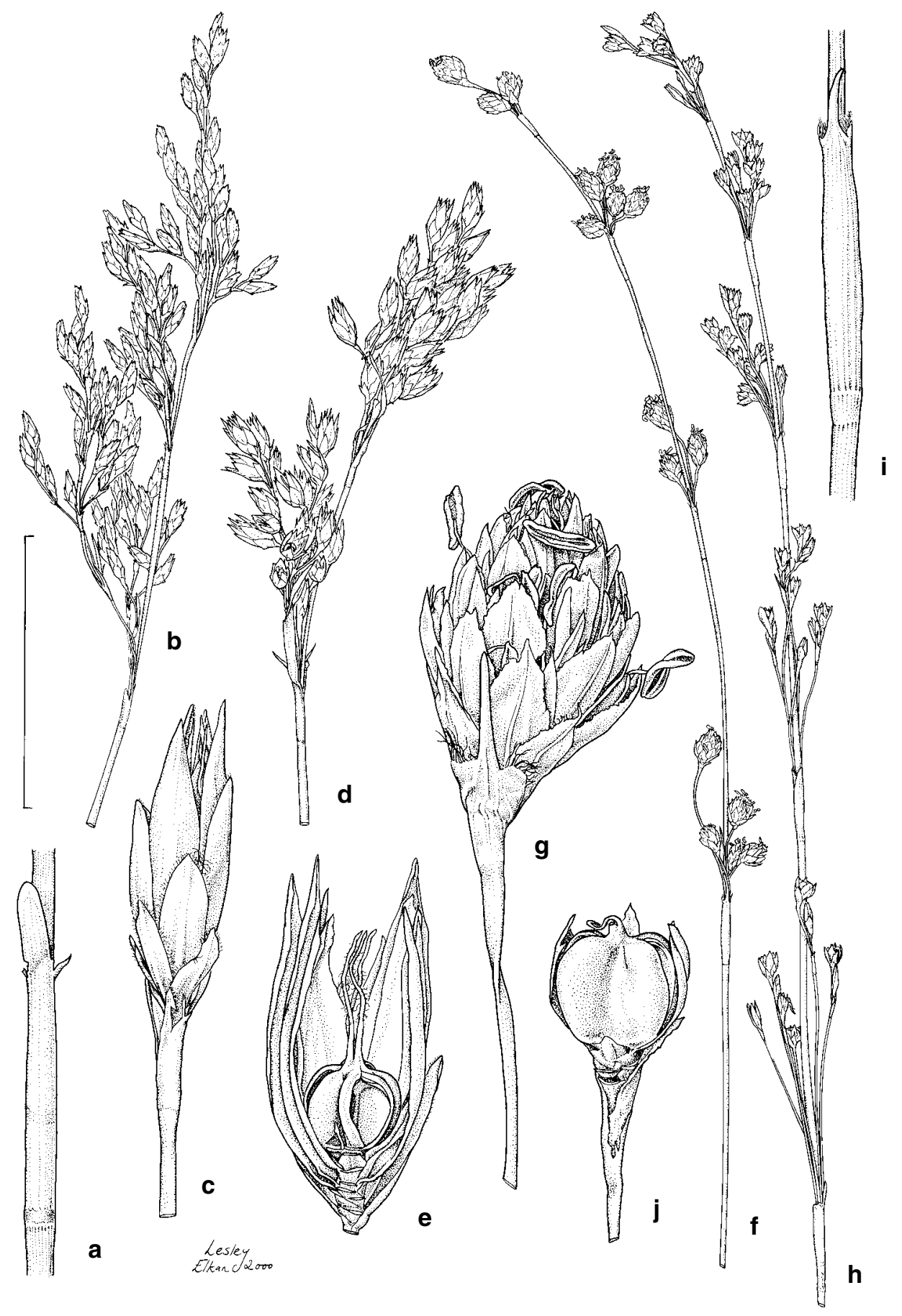

Fig. 4. a-e. Platychorda rivalis. a, b \& c male: a, culm sheath; b, inflorescence; c, spikelet (Macfarlane 2494 \& Annels); d \& e, female: d, inflorescence, e, capsule with tepals and glumes (Macfarlane 2560 $\mathcal{E}$ Annels). f-j, Tremulina cracens. f \& g, male: f, inflorescence; g, spikelet (Meney 911 \& Pate); $\mathrm{h}-\mathrm{j}$, female: $\mathbf{h}$, inflorescence, $\mathbf{i}$, culm sheath, $\mathbf{j}$, capsule (Briggs 6931b). Scale bar: $\mathbf{a}=2 \mathrm{~cm} ; \mathrm{b}, \mathrm{d}, \mathbf{f}$, $\mathrm{h}=3 \mathrm{~cm} ; \mathrm{c}, \mathrm{e}, \mathrm{g}, \mathrm{j}=3.75 \mathrm{~mm} ; \mathrm{i}=1 \mathrm{~cm}$. 
Conservation status: known from only a very few plants in a single valley swamp, but poorly known (Meney, Pate, Dixon, Briggs, \& Johnson 1999). In the CALM conservation categories a classification of vulnerable (P2) applies, at least until further study and monitoring is done. It occurs in a habitat of restricted extent but in an area where natural vegetation has been retained over a considerable region.

Specimens examined: Western Australia: Spearwood Creek, 5 Feb 1990, McCutcheon 2200 \& (PERTH); Spearwood Creek, (details as for type), McFarlane 2594, 2599 o , 2591 \& E Annels (PERTH, MJP, NSW), 2598 (PERTH); Spearwood Swamp, Denny Rd. 9 km W of Sues Rd., 28 Aug 1998, Briggs 9439 o (NSW, CANB, MEL, PERTH), 9438 q (NSW, PERTH).

Tremulina B.G. Briggs \& L.A.S. Johnson

As with Platychorda, Tremulina was established (Briggs \& Johnson 1998) to accommodate a species that had originally been named within Restio, and another related to it but unnamed. Tremulina is distinguished by the following combination of features: tepals 5 or 6 , ovary loculi 2, style branches 2, culm chlorenchyma lacking pillar cells but interrupted by sclerenchyma girders, seeds with a distinctive regular pattern of flat rectangular cells. It is typified by T. tremula (R. Br.) Briggs \& Johnson, which occurs in seasonally wet sites from Perth to Albany. T. cracens, described below, is limited to part of the same region.

Tremulina cracens B.G. Briggs E L.A.S. Johnson, sp. nov.

A Tremulina tremula combinatione characterum sequentium distinguitur: culmi graciliores, $0.8-1.0 \mathrm{~mm}$ diametro; vaginae culmorum breviores, $10-30 \mathrm{~mm}$ longae, laminis 2-3 mm longis; spiculae masculinae $3.5-5 \mathrm{~mm}$ longae; spiculae femineae $2-4.5 \mathrm{~mm}$ longae.

Type: Western Australia: Thomson Road c. 8 km NW of Mt Frankland, c. $20 \mathrm{~km} \mathrm{~N}$ of Walpole, 20 Nov 1977, B.G. Briggs 6931 o 9 (holo NSW; iso PERTH).

Caespitose, forming slender tussocks. Base with short (to $1 \mathrm{~cm}$ ), pale brown, scarious scales partly covering a pale brown woolly pubescence. Culms erect, straight, slender, terete to slightly compressed, unbranched and with 2-4 internodes below the inflorescence, $20-60 \mathrm{~cm}$ long, $0.8-1.0 \mathrm{~mm}$ diam., striate, green, glabrous, $4-10 \mathrm{~cm}$ long. Culm sheaths closely appressed, 7-12 mm long, green, striate; apex truncate with a linear, erect or slightly incurved lamina, 2-3 mm long; apical margin narrowly membranous, shortly ciliate. Inflorescence: $1-6$ filiform branches arising at each upper culm node; branches to $3.5 \mathrm{~cm}$ long but often much shorter, often with several internodes, occasionally branched, with a single terminal spikelet or both axillary and terminal spikelets. Spikelets globose to ovoid; glumes lanceolate-ovate, scarious, glossy, dull tan-brown, acute, shortly ciliate, $2.0-2.5 \mathrm{~mm}$ long; with or without a small mucro. Male spikelets 3.5-5.0 mm long, 2-3 mm wide, with 1-4 sterile lower glumes and 6-25 fertile upper glumes. Female spikelets 2-4.5 mm long, 2-3 mm wide; 1-2flowered, with up to 4 sterile lower glumes. Flowers: tepals 6, linear-lanceolate, acute, glossy, tan-brown, hyaline; 2 outer tepals keeled, with a few hairs along keel; inner tepals flat, slightly shorter, glabrous. Male flowers: tepals 1.8-2.3 mm long; stamens 3; filaments c. $2.0 \mathrm{~mm}$ long; anthers c. $1 \mathrm{~mm}$ long, exserted; pistillode minute or absent. Female flowers: staminodes 3; styles 2, very shortly connate. Capsule smooth, brown, 1.5-2 mm long. Seed ellipsoid, glossy, dark brown, c. $1.2 \mathrm{~mm}$ long. (Fig. 4f-j).

The epithet is from the Latin, cracens, slender, graceful; the plants are slender and graceful in comparison with the robust T. tremula.

Distribution: occurs in Western Australia on the Scott River Plains from Augusta to south of Manjimup, Windy Harbour, and to near Walpole. Grows in sand or peat, seasonally inundated, near permanent watercourses. 
Conservation status: rare, CALM priority code P3 (Meney, Pate, Dixon, Briggs, \& Johnson 1999). Known from only a few sites, in habitats of limited occurrence, but in an area where much natural vegetation has been retained.

T. cracens differs from $T$. tremula in the slender culms which are terete to slightly compressed (0.8-1.0 mm diam), lamina of culm sheaths linear and 2-4(-7) $\mathrm{mm}$ long, and spikelets small (male spikelets 3.5-5.0 mm long, 2-3 mm wide; females 2-4.5 mm long, 2-3 mm wide). T. tremula has strongly compressed culms $2.0-4.5 \mathrm{~mm}$ broad, lamina of culm sheath broad and blunt (3-11 mm long), and spikelets larger (male spikelets 4-6.5 mm long, 3-4 mm wide; females 4.5-5.0 $\mathrm{mm}$ long, 3-5 mm wide).

Specimens examined: Western Australia: Darling: $24.4 \mathrm{~km} \mathrm{~S}$ of Manjimup on South Western Hwy, 7 Jan 1989, Meney \& Dixon ơ (KPBG); Muirs Hwy, 1993 Meney $914 b$ đิ (KPBG, NSW); Scott River Plain, 24 Oct 1948, Royce 2931 ô, 2932 ๆ (PERTH); Lake Jasper, 21 Feb 1992, McCutcheon 2468 o (PERTH); Windy Harbour, 28 Sep 1954, Main ô (PERTH); Lower Shannon flats, W of Shannon R., 20 Mar 1995, Hearn ARA 5370 ơ (PERTH, NSW); N of Walpole (details as for type) Briggs 6931a, 6932 ơ (NSW), 6933 ô, 6934 \& (NSW, PERTH); Weld Rd and Rainbow End, Walpole, Jan 1991, Meney 911 \& Pate ô, क (KPBG, NSW).

\section{Acknowledgments}

Many colleagues assisted our studies on Restionaceae. Peter Wilson advised on the Latin diagnoses; Carolyn Porter, Siegfried Krauss, Barbara Wiecek and others gave technical assistance; David Mackay, Lesley Elkan and Catherine Wardrop were responsible for the illustrations. Kathy Meney of Kings Park and Botanic Garden and John Pate of the University of Western Australia shared information with us most generously and assisted in the field. The Western Australian Herbarium made available its resources of specimens; Terry Macfarlane and colleagues at its regional herbarium at Manjimup provided collections and assistance in the field. Our thanks go to all who assisted in these many ways.

\section{References}

Briggs, B.G. \& Johnson, L.A.S. (1998) New genera and species of Australian Restionaceae (Poales). Telopea 7: 345-373.

Briggs, B.G. \& Johnson, L.A.S. (1999) A guide to a new classification of Restionaceae and allied families. Pp. 25-56 in Meney, K.A. \& Pate, J.S. (eds) Australian Rushes, Biology, Identification and Conservation of Restionaceae and allied families. (University of Western Australia Press: Nedlands).

Briggs, B. G. \& Johnson, L.A.S. (2001) The genus Desmocladus (Restionaceae) and new species from the south of Western Australia and South Australia. Telopea 9(2): 227-245.

Briggs, J.D. \& Leigh, J.H. (1996) Rare or Threatened Australian Plants. (CSIRO: Collingwood).

Diels, L. (1906) Die Pflanzenwelt von West-Australien südlich des Wendekreises. (Engelmann: Leipzig).

Linder, H.P., Briggs, B.G. \& Johnson, L.A.S. (1998) Restionaceae. Pp. 425-445 in Kubitski, K. (ed.) The Families and Genera of Flowering Plants, vol 4. (Springer-Verlag: Berlin).

Meney, K. A., Pate, J. S. \& Dixon, K. W. (1996) New species of Restionaceae from Western Australia. Telopea 6: 649-666.

Meney, K. A., Pate, J. S. \& Hickman, E. J. (1999) Morphological and anatomical descriptions of Restionaceae and allied families and their distribution. Pp. 161-461 in Meney, K.A. \& Pate, J.S. (eds) Australian Rushes, Biology, Identification and Conservation of Restionaceae and allied families. (University of Western Australia Press: Nedlands).

Meney, K.A., Pate, J.S., Dixon, K.W., Briggs, B.G. \& Johnson, L.A.S. (1999) Conservation of Australian Restionaceae. Pp. 465-480 in Meney, K.A. \& Pate, J.S. (eds) Australian Rushes, Biology, Identification and Conservation of Restionaceae and allied families. (University of Western Australia Press: Nedlands). 